\title{
Grand Union between Tibet and Mongolia: Unfulfilled Dream of the 13th Dalai Lama
}

\author{
Ts. Batbayar (Mongolia)
}

ince the late sixteenth century when Altan Khan of Tumed in Southern
Mongolia adopted the Yellow Hat sect of Tibetan Buddhism and sup-
ported it as the common faith of the Mongol people, the teaching and discipline of Buddhism greatly influenced the customs, society, and various activities of the nomadic Mongols. The Mongolian version of Tibetan Buddhism was called Lamaism, and the Buddhist monks were known as lamas.

The highest ranking lama of Northern or Khalkha Mongolia was the wellknown Jebtsundamba Khutagt. His first and second incarnations were born in the house of Tusheet Khan, the most influential one of four Khans of Khalkha Mongolia. They were recognized as spiritual leaders of Mongolia with high prestige in Mongolian politics. Consequently, the Manchu court in Peking became anxious of the prospects of a reunified Mongolia under their leadership. In order to prevent such perspective the Manchu emperor issued the unwritten regulation by which the third and its subsequent incarnations of the Jebtsundamba Khutagt were to be found in Tibet instead of Mongolia. ${ }^{1}$ The 8th Jebtsundamba Khutagt, who played an important role in the political life of modern Mongolia, was found as a boy in Tibet, and was brought to Mongolia in 1875 as a reincarnation of his predecessor.

\section{Mongolia and Tibet in the Beginning of the twentieth Century}

At the beginning of the twentieth century both Mongolian and Tibetan leaders faced an old dilemma in their search for protection from its Chinese neighbor. In the case of Mongolia, in 1911, with the collapse of the Manchu empire, Mongolia sought Russian help and proclaimed its independence. However, Tsarist Russia, restrained by secret treaties with Japan, was not willing to render full support for Mongolian independence and reunification. In the case of Tibet, it sought protection from Britain as a natural protector against Chinese domination. Britain, which persuaded the Qing dynasty to recognize its special interests in Tibet in a

1 Tsedendamba Batbayar, Modern Mongolia: A Concise History, Ulaanbaatar, 2002, p. 17. 
1906 agreement, however, was not determined to fight for Tibetan independence.

Two things were common to Mongolia and Tibet. Each country thought its relations with the Manchu Qing dynasty as a special arrangement, and they never recognized the Chinese Republic as a successor to the Qing dynasty. Second, both Tibet and Mongolia sought the foreign help to secure their independence.

It is evident that the geographical position of both countries and, their military and political vulnerability, seriously reduced the scope of their activities in foreign affairs. The fear of domination and eventual assimilation by China's huge population, was always at the heart of the Mongolian and Tibetan perception of the Chinese threat. ${ }^{2}$

\section{The Dalai Lama in Mongolia 1904-1906}

Because of Francis Younghusband's well known expedition to Lhasa the thirteenth Dalai Lama fled northwards to Mongolia in September 2004. This was the first time he had left his own country. He was then twenty-eight years old.

As Charles Bell wrote, "Eventually he crossed the border of Mongolia, inhabited by a race closely akin to the Tibetans, and covering an area more than onethird of the size of Europe. In November he arrived at the capital, Urga, fairly close to the Russian frontier in the north. Having seven hundred persons in his suite, his baggage was carried by a small army of camels. Over ten thousand citizens went several miles out of the town to meet him and prostrate themselves before him. Pilgrims flocked in from all parts of Mongolia, from Siberia, and from the steppes of Astrakhan, to do him homage."

The Dalai Lama stayed almost two years in Mongolia. Urga was the residence of the 8th Jebtsundamba Khutagt who was the highest ranking lama in Khalkha Mongolia. As Russian archive materials suggest, some kind of tension was created between the Dalai Lama and Khutagt. Khutagt also suffered financially because the Dalai Lama's stay brought some considerable financial burden on the ruler of Urga.

The British press was watching closely the forced exile of the Dalai Lama to Mongolia. Lieutenant-Colonel Waddell, the author of the book "The Buddhism of Tibet," wrote in "The Times": "The young Dalai bears the title of "the eloquent, noble minded Tubdan". Temporal sovereign of Tibet, his spiritual authority extends through Tibet and along the Himalayan Buddhist states to Ladak and Baikal, to Mongolia and China, as far as Peking." He also wrote about the role of

Agvan Dorzhiev in the escape of the Dalai Lama from China. "On his escape from Chinese influence the unlucky young Dalai (30 years old) soon fell deeply

2 Ibid. p. 21.

3 Charles Bell, Portrait of a Dalai Lama: The life and Times of the Great Thirteens, Wisdom Publication, London, 1987, p.7. 
into Russian clutches, through the influence of his favorite tutor, the Lama Dorjieff. This man is a Mongolian Buriat from the shores of lake Baikal, and therefore a Russian subject by birth and a Lama by profession. He grew up and received his education in Russia, settled in Lhasa in one of the great convents there 20 years ago...He is a well-educated man, a member of the Russian Geographical Society, and has travelled over India and Ceylon several times on his way to Odessa and

St. Petersburg. Latterly he has been in charge of the arsenal at Lhasa. On getting the ear of the young Dalai Lama he poisoned his mind against the English, and led him to believe that Russia is his friend and not England."

All evidences suggest that the 13th Dalai Lama initiated the idea of establishing the Grand Union between Tibet and Mongolia during his forced exile in Mongolia in 1904-1906. Russian Archive materials suggest that the Dalai Lama was determined to pursue the Union between Tibet and various parts of Mongolia, Southern Mongolia, Northern Mongolia and other parts of Mongolia. As Russian consular official Lyuba wrote from Urga in July 1905, some Mongolian princes from Eastern Mongolia asked the Dalai Lama to advise them about their planned union of eastern Mongolian aimaks with the ultimate aim to establish an independent kingdom separate from China but under the protection of Russia. As Lyuba mentioned the Dalai Lama was ready to support those Mongolian princes in case Russia had sympathy for them. In September 1905 the Dalai Lama met Russian consular official Kuzminskii in Urga and talked about the plans of Mongolian princes in more detail. Almost all princes of Jerim aimak, two princes from Uzumchin, two princes from Sunit, Zhasagtu van from Horchin aimak and other princes from Eastern and Southern Mongolia sent similar requests to the Dalai Lama. The Dalai Lama mentioned chin van Khanddorj, and the Mongolian Governor of Uliasutai and other princes and high- ranking lamas of Northern Khalkha Mongolia as supporters of that great project. The Dalai Lama thought that the project was feasible although it could not be implemented soon. The Dalai Lama requested moral support from Russia toward those Mongolian princes so that they could feel some kind of protection in their actions and could seek a shelter in Russia if needed. ${ }^{5}$

In June 1905, M. Pokotilov, the new Russian minister to China, arrived in Urga on his way to Peking and met the Dalai Lama obviously giving him some personal gifts from the Russian Tsar. As M. Pokotilov wrote from Urga the Dalai Lama told him two important things. First, the Dalai Lama would like to appeal to major powers to convene a special international conference on the Tibetan issue. Second, the Dalai Lama wished Russia would get the same rights in Tibet as Britain possessed in Tibet. ${ }^{6}$

4 “The Times", August 13, 1904.

5 “Archive of Russian Empire’s Foreign Policy, Moscow, Fond: Mission in Peking”, Opis 761, delo 413. List.

245-247, "Report of Kuzminskii from Urga to G.A. Kozakov in St. Petersburg, 4 September, 1905".

6 The same Archive, Fond. Mission in Peking, Opis 761, delo 413, list 173, report by Pokotilov from Urga 
The Dalai Lama's tutor Agvan Dorzhiev went to St Petersburg to seek the audience with the Tsar. However, as John Snelling wrote, 1905 was an acute crisis year for the Russian autocracy because of the Russo-Japanese war; therefore Agvan Dorzhiev's mission was not so successful. ${ }^{7}$ Towards the end of his time in Mongolia, the Dalai Lama left Urga for Uliasutai and elsewehere in Sain Noyon Khan aimak, where he was hosted by local princes. Most notably, chin van Khanddorj, one of the leaders of the national revolution in 1911-1912, invited the Dalai Lama to his monastery called Vangiin Khuree to spend some time there. As Mongolian historian J. Boldbaatar wrote chin van Khanddorj benefited a lot from the Dalai Lama in terms of his wisdom and concern about the future of Tibet and Mongolia. $^{8}$

\section{Treaty between Mongolia and Tibet}

In November 1912 Agvan Dorzhiev again visited Urga. Russian minister I.Y. Korostovets was in Urga having just concluded the Russo-Mongolian agreement and protocol which resulted in huge Russian trade benefits and rights. Agvan Dorzhiev met Korostovets in Urga and proposed to establish a mutual BritishRussian protectorate over Tibet and to eliminate Chinese sovereignty. Korostovets, however, was extremely cautious and advised Dorzhiev to abandon the idea of the protectorate and instead to reach an understanding with the British. ${ }^{9}$

The international position of both Tibet and Mongolia was extremely weak. Both had totally failed to get diplomatic recognition from any of the powers, and their diplomatic success came with the conclusion of a treaty between Tibet and Mongolia early in 1913. The treaty was signed by Dorzhiev and two Tibetans on behalf of the Dalai Lama, and by two Mongolian ministers for the Jebtsundamba Khutugt. The agreement consisted of nine articles. ${ }^{10}$ Articles 1 and 2 mutually recognized the independence of the two countries. Both the Dalai Lama and the Jebtsundamba Khutagt recognized each other as the Ruler of Tibet and Mongolia, respectively. Article 3 stated that both states would work for the well-being of the Buddhist faith. According to the agreement, Mongolia and Tibet were determined "to render a help to each other against internal and external threats now and forever." This can be interpreted to mean that Mongolia and Tibet agreed to establish an alliance. The agreement was most probably suggested by the thirteenth Dalai Lama, who during his stay in Mongolia in 1905-6, was committed to

\footnotetext{
7 John Snelling, Buddhism in Russia: The Story of Agvan Dorzhiev, Lhasa's Emissary to the Tsar, Element Books limited, 1993, p. 121.

8 J. Boldbaatar, The Mongol teacher of the Dalai Lama, Ulaanbaatar, 1995, pp.10-11. (in Mongolian)

9 I.Y. Korostovets, From Chinggis Khan up to the Soviet Republic, Ulaanbaatar, "Emgent” printing, 2004, pp. 289-291. (in Russian)

10 The original text of the Mongol-Tibetan treaty, The Archive of the Ministry of Foreign Affairs, Ulaanbaatar, Mongolia, Both the Mongolian and the Tibetan texts are deposited in this Archive.
} 
the political alliance between Mongolia and Tibet on a religious platform.

The treaty also included an article specifying the protection of both nationals traveling officially or privately in affairs of religion or state. Both states declared that they would engage in reciprocal trade in the products of their re

spective countries including wares and cattle. They also agreed to open industrial establishments. The agent of the Tibetan bank in Urga served as a regular means of communication, every month or two he wrote to the Prime Minister of Tibet.

In terms of great power manipulations, Mongolia's case is interesting when compared with the case of Tibet. If the interests of China and Russia were involved mostly in Mongolia, the interests of Russia and Britain were involved mostly in Tibet. Both cases underwent very similar developments. As Mongolia was divided into Outer and Inner Mongolia in 1913 by Russia and China, Sir Henry McMahon devised a plan for the partition of Tibet into inner and outer zones in December 1913. The Simla Conference took place from October 1913 through June 1914, while the Kyakhta Conference took place from September 1914 to June 1915.

During the Conference between Britain, China and Tibet held at Simla in 1913-1914, it was stated that Tibet and Mongolia had signed a treaty of alliance. Russia claimed such a treaty had been concluded. As Mongolia was dominated by the Russians, the British felt such a treaty would endanger British interests in Tibet. It was believed that the Dalai Lama gave Agvan Dorjzhiev a letter authorizing him to conclude a treaty. However, the Prime Minister of the Tibetan Government denied that the Dalai Lama gave Dorzhiev any such authority, claiming instead that the letter was of a general nature asking Dorzhiev to work for the well-being of the Buddhist faith.

The three-way Conference for Mongolia met for nearly a year in 1914 and 1915 and produced the Kyakhta treaty, composed of twenty-two articles and signed by representatives of Mongolia, Russia, and China on June 7, 1915. It reaffirmed the autonomy of "Outer Mongolia" only, excluding other parts of Mongolia, under Chinese suzerainty. Urga and Beijing ceased hostilities and withdrew their armies, and China was permitted to station ambans or residents in Mongolia. The Simla Conference, convened between October 1913 and July 1914, produced a similar convention, which was signed by two parties, Tibet and Britain. The Chinese government's refusal to sign the Simla convention left the status of Tibet ambiguous and led to the Tibetan military campaign in Eastern Tibet in 1917-18.

The Republic of China tried to reassert its suzerainty over Tibet and Mongolia which were considered inseparable parts of China. In May 1924, the Chinese persuaded Soviet Russia to recognize formally its suzerainty over "Outer Mongolia" as a part of China. However, with the death of the Jebtsundamba Khutagt, the Soviet Union recognized Mongolia as a People's Republic in 1924 and took the 
firm course to turn Mongolia into a close ally and a Soviet show-case. In 1946, the Republic of China accepted the independent status of the Mongolian People's Republic under the pressure of Soviet leader Joseph Stalin. In case of Tibet, the Nanking government thought the death of the 13th Dalai Lama in 1933 as an opportunity to reassert its control over Tibet. However, it met strong resistance from the religious circles of Tibet up until 1951. 